\title{
New foliage growth is a significant, unaccounted source for volatiles in boreal evergreen forests
}

\author{
J. Aalto ${ }^{1,2}$, P. Kolari ${ }^{2,3}$, P. Hari ${ }^{2}$, V.-M. Kerminen ${ }^{3}$, P. Schiestl-Aalto ${ }^{1,2}$, H. Aaltonen ${ }^{2, *}$, J. Levula ${ }^{1}$, E. Siivola ${ }^{3}$, \\ M. Kulmala ${ }^{3}$, and J. Bäck ${ }^{2,3}$ \\ ${ }^{1}$ SMEAR II station, University of Helsinki, 35500 Korkeakoski, Finland \\ ${ }^{2}$ Department of Forest Sciences, P.O. Box 27, University of Helsinki, 00014 Helsinki, Finland \\ ${ }^{3}$ Department of Physics, P.O. Box 64, University of Helsinki, 00014 Helsinki, Finland \\ *now at: Finnish Meteorological Institute, P.O. Box 503, 00101 Helsinki, Finland
}

Correspondence to: J. Aalto (juho.aalto@helsinki.fi)

Received: 27 September 2013 - Published in Biogeosciences Discuss.: 21 November 2013

Revised: 24 January 2014 - Accepted: 25 January 2014 - Published: 6 March 2014

\begin{abstract}
Estimates of volatile organic compound (VOC) emissions from forests are based on the assumption that foliage has a steady emission potential over its lifetime, and that emissions are mainly modified by short-term variations in light and temperature. However, in many field studies this has been challenged, and high emissions and atmospheric concentrations have been measured during periods of low biological activity, such as in springtime. We conducted measurements during three years, using an online gas-exchange monitoring system to observe volatile organic emissions from a mature (1 year-old) and a growing Scots pine shoot. The emission rates of organic vapors from vegetative buds of Scots pine during the dehardening and rapid shoot growth stages were one to two orders of magnitude higher than those from mature foliage; this difference decreased and finally disappeared when the new shoot was maturing in late summer. On average, the springtime monoterpene emission rate of the bud was about 500 times higher than that of the mature needles; during the most intensive needle elongation period, the monoterpene emission rate of the growing needles was 3.5 higher than that of the mature needles, and in September the monoterpene emission rate of the same years' needles was even lower $(50 \%)$ than that of the previous years' needles. For other measured compounds (methanol, acetone and methylbutenol) the values were of the same order of magnitude, except before bud break in spring, when the emission rates of buds for those compounds were on average about 20-30 times higher than that of mature needles. During spring and early summer the buds and growing
\end{abstract}

shoots are a strong source of several VOCs, and if they are not accounted for in emission modeling a significant proportion of the emissions - from a few percent to even half of the annual cumulative emissions - will remain concealed. The diurnal emission pattern of growing shoots differed from the diurnal cycle in temperature as well as from the diurnal emission pattern of mature shoots, which may be related to processes involved in shoot or needle elongation. Our findings imply that global estimations of monoterpene emission rates from forests are in need of revision, and that the physiological state of the plants should be taken into account when emissions of the reactive gases such as monoterpenes are estimated.

\section{Introduction}

The current understanding of the role of biogenic feedback to atmospheric reactivity involves large uncertainties. The measured atmospheric concentrations of many reactive gases, for example terpenoids (mainly isoprene, mono- and sesquiterpenes), exhibit huge spatial and temporal variations due to factors related to large variation in emission rates and emission composition between or intra-species (Kesselmeier and Staudt 1999; Bäck et al., 2012), to light, temperature and ozone-concentration-related variations in incident emission rates (Guenther et al., 1993; Komenda and Koppman, 2002; Tarvainen et al., 2005; Bourtsoukidis et al., 2012) as well as to transport and chemical reactions in the air (Rinne et 
al., 2007). Longer-term variations, due to for example leafing and senescence of foliage, have also been recognized as affecting the emission rates (Karl et al., 2003, Hakola et al., 2006; Geron and Arnts, 2010), the maximum rates being observed in the midsummer when leaves are fully mature.

The current models for global terpenoid emission rates mainly use emission potentials defined for mature foliage under standard (constant) conditions (upscaled with biomass estimates for specific plant functional types) and their regional distribution, modified by the prevailing irradiation and temperature ("Guenther approach", Guenther et al., 2006, 2012). However, these semi-empirical algorithms do not account for many inherent plant physiological processes that may produce large seasonal variations in the synthesis and emission rates of terpenoids, thus the different model estimates have large uncertainties in total emission rates (Arneth et al., 2008; Niinemets et al., 2010). The few models empirically replicating the seasonal phenomena still assume no dependence of emission potential on the leaf developmental stage in evergreen plants (Staudt et al., 2000), or use an arbitrarily defined scaling factor for modifying the emission rate according to leaf age (Guenther et al., 2012). Further, these models concentrate mainly on isoprene, whereas model development describing the emissions of monoterpenes or oxygen-containing compounds (methanol, acetone) has been less successful (Arneth et al., 2008; Galbally and Kirstine, 2002), although in evergreen vegetation, especially, these compounds may form up to $90 \%$ of emissions (Rinne et al., 2009). The seasonality has to some extent been implemented in process-based models describing the enzyme activity changes over seasons, such as in SIM-BIM (Grote et al., 2006; see also discussion in Grote and Niinemets, 2008; Niinemets et al., 2010; and Monson et al., 2012). However, the phenology-submodel in SIM-BIM suggests that the monoterpene emission onset happens only a few weeks after leaf emergence, and that the maximum emission rates take place in fully grown, current year leaves (Fischbach et al., 2002). Thus, the processes during leaf development and expansion are not taken into account in these models.

In all ecosystems, the annual cycle of perennial vegetation includes both active and inactive periods, which involve profound modifications in processes at molecular-, cellularand organ-scale. In boreal evergreens the increased freezing tolerance - a prerequisite for sustained foliage retention - is provided by hardening in the fall. Hardening leads to an inactive rest period (dormancy) in both mature foliage and in newly formed buds housing the next year's annual growth. The driving factor for dormancy release and subsequent metabolic activation in both mature tissues and developing buds is temperature change (Rohde and Balerao, 2007; Hänninen et al., 2007). The recovery from dormancy, reactivation of metabolism and onset of growth in spring takes place in two phases: the release of true dormancy leads first to a quiescent phase lacking any visible signs of growth, and only when dormancy is fully released can the new growth start. In the quiescent phase, environmental cues activate the expression of genes, encoding enzymatic pathways to synthesize new macromolecules for growth (Heide, 1993; Rohde and Balerao, 2007; Sutinen et al., 2009). During the active period, biomass growth takes place by formation of new tissues in meristems, involving the formation, differentiation and expansion of new cells, tissues and organs. Such phenological events require environmental cues, which activate the enzymatic pathways leading to synthesis of new macromolecules for growth (for example lignin and pectin for cell walls, carotenoids and chlorophyll for thylakoids, and lipids and proteins for cell membranes). Despite their great significance for vegetation, these strong turning points of the key metabolic processes have not been implemented in emission estimates so far.

We were motivated by the knowledge that atmospheric aerosol formation and growth are closely linked to concentrations of their organic precursors (e.g., terpenoids), originating from biosphere processes (Kulmala et al., 2013). It is well documented that in a wide variety of environments, the aerosol formation events are peaking in springtime (Dal Maso et al., 2005; Manninen et al., 2010), but the reasons for this are still unclear. We hypothesized that we would observe high VOC emission rates from Scots pine branches in spring, and that the high spring emissions would be related to dormancy release and growth initiation in vegetative buds. To study this, we set up to measure the seasonal and diurnal patterns in emissions in both mature and growing foliage of Scots pine trees in field conditions, using an automated enclosure system with sufficient time resolution.

\section{Material and methods}

\subsection{Smear II measurement station}

The measurements were conducted at the SMEAR II measurement station (Station for Measuring Forest Ecosystem Atmosphere Relations) in Hyytiälä, southern Finland $\left(61^{\circ} \mathrm{N}\right.$, $24^{\circ} \mathrm{E} ; 180 \mathrm{~m}$ a.s.l). The forest at the station is dominated by Scots pine (Pinus sylvestris L.), and represents a managed boreal coniferous forest site with closed canopy. The stand was established after prescribed burning was conducted in 1962. Currently the canopy reaches a height of ca. $17 \mathrm{~m}$, with crown base height at ca. $10 \mathrm{~m}$. and one-sided leaf area index (LAI) of $2-2.5 \mathrm{~m}^{2} \mathrm{~m}^{-2}$. With a scaffolding tower we have access to the top of the canopy, where the enclosure measurements are located in the top whorls. More details about the site are given in Hari and Kulmala (2005).

\subsection{Emission measurements}

The gas exchange of shoots was measured with an automated gas-exchange system, consisting of two cylindrical shoot enclosures, Fig. 1), sampling tubing, as well as analyzers for $\mathrm{CO}_{2}, \mathrm{H}_{2} \mathrm{O}$ and VOCs (volatile organic compounds) (Altimir 


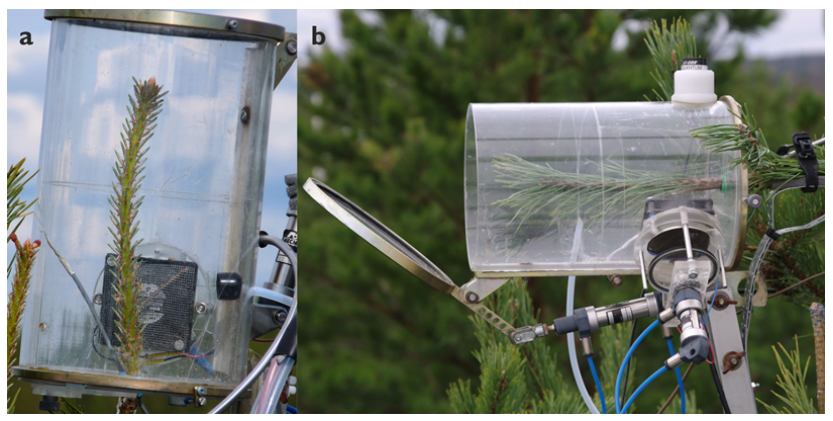

Fig. 1. Emission measurements with dynamic shoot enclosures. (a) The enclosure with a developing Scots pine shoot at the end of May, when the intensive needle elongation period begins. (b) The enclosure with a mature Scots pine shoot.

et al., 2002). The enclosures are made of acrylic plastic and their inner surfaces are coated with fluorinated ethylene propylene (FEP) film. The enclosures remained open most of the time and closed intermittently for measurements, typically four successive 3 min periods in 3-hour intervals. While open, the interior was in contact with ambient unfiltered air. During a closure, an air sample $\left(1 \mathrm{dm}^{3} \mathrm{~min}^{-1}\right)$ was drawn from the enclosure to the gas analyzers along the sample lines. Ambient air was allowed to enter the enclosure through small holes in the chamber walls to compensate for the sample air flow taken from the chamber. The air temperature inside the enclosure and photosynthetically active photon flux density (PPFD) was measured before and during the closure, and the values were recorded at $5 \mathrm{~s}$ intervals, using thermocouples (copper-constantan) or PT100 for temperature and a LI-COR LI-190 quantum sensor (LI-COR Environmental, USA) as a PPFD sensor. During the closure the temperature inside the enclosure tended to increase, especially during the daytime when the increase in temperature during the closure was typically $2-4^{\circ} \mathrm{K}$. The PPFD sensor was located outside the chamber and represented ambient conditions.

Measurements were conducted during the years 2009, 2010 and 2011. Shoot enclosures (volumes 3.5 and $4.5 \mathrm{dm}^{3}$; Fig. 1a, b) were installed for unshaded top-canopy branches during the previous mid-winter or earlier: one with a mature shoot inside (hereafter "mature shoot") and the other with only a terminal bud inside the chamber (hereafter "developing shoot"). All buds of the mature shoot and all auxiliary buds of the developing shoot were gently removed about 1 month before the installation to avoid contamination with fresh resin flowing from the scars (Hakola et al., 2006).

The subsample for VOC analysis $\left(0.1 \mathrm{dm}^{3} \mathrm{~min}^{-1}\right)$ was taken from a sample line with a $1 \mathrm{dm}^{3} \mathrm{~min}^{-1}$ sample flow. During 2010 and 2011, heated $\left(5 \mathrm{~W} \mathrm{~m}^{-1}\right)$ fluorinated ethylene propylene (FEP) tubing (length $64 \mathrm{~m}$, internal diameter $4 \mathrm{~mm}$ ) lead the sample air towards the $\mathrm{CO}_{2}$ and $\mathrm{H}_{2} \mathrm{O}$ analyzers, and the VOC subsample was taken from that line before the other analyzers. During 2009 the sample for the VOC analysis was taken with a separate $50 \mathrm{~m}$-long FEP (internal diameter $4 \mathrm{~mm}$ ) tube with no other analyzers connected to the tube. The subsample for VOC analysis with a high-sensitivity PTR-QMS (proton transfer reaction-quadrupole mass spectrometer; Ionicon Analytik GmbH, Innsbruck, Austria) was drawn through a polytetrafluoroethylene (PTFE) tube with an internal diameter of $1.57 \mathrm{~mm}$ and length of about $5 \mathrm{~m}$. The total retention time of the sample tubing was about $40 \mathrm{~s}$ in 2009 and $55 \mathrm{~s}$ in 2010-2011. For details of the maintenance, calibration and volume mixing ratio calculations of PTR-QMS, see Taipale et al. (2008). The PTR-QMS measures the volume mixing ratio of all compounds having equal mass with a resolution of $1 \mathrm{amu}$ (atomic mass unit) and was operated here with a $12.5 \mathrm{~s}$ measurement interval and an integration time of $1 \mathrm{~s} \mathrm{amu}^{-1}$. The measured protonated masses and the potential contributing compounds were M33 (methanol), M59 (acetone), M69 (dehydrated methylbutenol (MBO) fragment, hereafter MBO) and M137 (monoterpenes) (de Gouw and Warneke, 2007). The lower limit of detection was ca. 50100 pptv (Taipale et al., 2008).

Calibration of the PTR-QMS was conducted 2-4 times per month using a bottled standard gas containing ca. $1 \mathrm{ppmv}$ methanol, acetone, isoprene and $\alpha$-pinene (Apel-Riemer Environmental Inc., USA, and Ionimed $\mathrm{GmbH}$, Austria). In the calibration, the standard gas was diluted close to the atmospheric concentrations (5-20 ppbv) using a catalytic converter (Parker ChromGas Zero Air Generator, model 3501, USA). The VOC emission rates were measured and calculated by applying a mass balance equation to the concentration change during the chamber closure (Kolari et al., 2012). The emission rate calculation was conducted per dry needle mass, which was determined at the end of each measurement period, typically in November. The specific leaf area for year 2009 was $0.011 \mathrm{~m}^{2} \mathrm{~g}^{-1}$, and for years 2010-2011 $0.009 \mathrm{~m}^{2} \mathrm{~g}^{-1}$.

The mass spectrometer technique used only distinguished compounds based on their molecular mass, and thus one mass can include several compounds or their fragments. The protonated $69 \mathrm{amu}$ includes both a dehydrated fragment of MBO and isoprene (de Gouw and Warneke 2007). Many pine species (including Scots pine) are known to emit considerable amounts of MBO, but only negligible amounts of isoprene (Zeidler and Lichtenthaler 2001, Tarvainen et al., 2005; Gray et al., 2006). Based on this result, and the previous GC-MS measurements from same trees conducted by Tarvainen et al. (2005) and Hakola et al. (2006), we assume that in this case the measured emission at $69 \mathrm{amu}$ is mainly composed of the MBO fragment. However, as PTR-MS is mass-specific, we cannot exclude the potential traces of isoprene and certain aldehydes and ketones in the M69 (Fall et al., 2001; Warneke et al., 2003), if they are emitted from Scots pine shoots. 


\subsection{Shoot and needle elongation}

In order to evaluate the influence of shoot and needle growth on emission patterns, the growth of pine shoot and needles were measured 1-3 times per week starting from the beginning of the elongation period, i.e., from the latter part of April, until September. Measurements were conducted with the help of digital photographs taken at a distance of at least 2 meters; the length of the shoot and 6-10 randomly chosen needles were measured from the photographs using the width of the enclosure as a scale. The theoretical accuracy of the measurement method is $0.065 \mathrm{~mm}$, and practical repeatability is below $1 \mathrm{~mm}$. The length of the next terminal bud (formed during July-August) was excluded from the shoot length results. In order to analyze the effect of enclosure environment on growth, the shoot and needle elongation was measured both inside and outside of the enclosure for four branches. The measured results were interpolated using a shoot and needle elongation model based on inherent growth rhythms driven by temperature (Schiestl-Aalto et al., 2013). Inside the enclosure, the most intensive needle elongation days (needle elongation rate $\geq 0.5 \mathrm{~mm}^{-1}$ ) took place between 1 June and 25 July. The total needle elongation period was 104 days in 2009 and 2010, and 102 days in 2011.

To obtain information about diurnal timing of shoot elongation, the shoot elongation was also measured using a continuous measurement method. The shoot length change was measured using a Solartron Mach1 free carrier magnetic core with BIM interface unit (Solartron Metrology, Bognor Regis, UK). The diurnal shoot elongation pattern was measured only outside of the enclosure and we suppose that the diurnal timing of shoot elongation inside enclosure closely resembles that outside the enclosure because the patterns of driving factors, mostly temperature, are almost identical.

\subsection{Estimation of the contribution of developing needle age class to the whole canopy emission}

To estimate the stand-level contribution of the emissions from developing foliage compared to the emissions from the whole canopy, three simplifying assumptions were applied:

1. All remaining needle age classes have the same mass per land area in the autumn. This assumption is based on the fact that the canopy closure took place several decades ago and therefore the stand needle mass is rather constant (Vose et al., 1994); thus there is no major difference in yearly new foliage production.

2. The oldest needle age class falls out at the same time as the elongation of the developing needle age class so that the stand needle mass is considered stable over the growing season. According to Rautiainen et al. (2012) the Scots pine stand needle mass in southern Finland is relatively constant over the growing season and the trees have on average three needle age classes.
3. All needle age classes at the same canopy height face identical (light and temperature) environmental conditions. The canopy structure and growth mode of Scots pine produce an almost even spatial distribution of all living needle age classes. The spatial distribution is to some extent skewed so that the newest needle age class is shading the older ones, but because the Scots pine canopy is fairly sparse, the light and thermal conditions of all needle age classes are almost identical.

Based on the above assumptions, the contribution of the developing needle age class to the whole canopy emissions $\left(C_{\mathrm{D}}, \%\right)$ is

$C_{\mathrm{D}}=\frac{m_{\mathrm{D}} E_{\mathrm{D}}}{m_{\mathrm{M}} E_{\mathrm{M}}+m_{\mathrm{D}} E_{\mathrm{D}}}$,

where $m_{\mathrm{D}}$ is the mass of developing needles per unit area $\left(\mathrm{g} \mathrm{m}^{-2}\right), E_{\mathrm{D}}$ is the VOC emission rate of the developing needles $\left(\mathrm{ng} \mathrm{g}^{-1} \mathrm{~s}^{-1}\right), m_{\mathrm{M}}$ is the mass of mature needles and $E_{\mathrm{M}}$ is the emission rate of the mature needles, with units corresponding to those of developing needles. $C_{\mathrm{D}}$ is unitless. The needle mass is assumed to be directly proportional to needle length.

Conventionally, the emission inventories have been based on the assumption that the developing and mature needle age classes have identical emission rates per needle mass or area (Guenther et al., 1993, Tarvainen et al., 2005). We next estimated the concealed proportion of emissions of this approach, if the high emissions from developing needles are not taken into account. The estimation is based on the reference values $E R_{C}$ and $E R_{R}$, representing a conventional approach and our results, respectively. The reference value $E R_{R}$ is

$\mathrm{ER}_{\mathrm{R}}=m_{\mathrm{M}} E_{\mathrm{M}}+m_{\mathrm{D}} E_{\mathrm{D}}$.

The reference value for the conventional approach $\left(\mathrm{ER}_{\mathrm{C}}\right)$ was calculated as follows:

$\mathrm{ER}_{\mathrm{C}}=m_{\mathrm{T}} E_{\mathrm{M}}$,

where $m_{\mathrm{T}}$ is the total mass of needles per area, with the unit corresponding to $m_{\mathrm{M}}$ and $m_{\mathrm{D}}$.

The reference values $E_{R}$ and $E_{C}$ were calculated only to allow for comparison between them, not to give estimates of stand scale emissions. We integrated the emissions of the stand both with our new method and with the conventional approach in order to estimate the proportion of concealed emissions in the conventional approach; the estimate was obtained by dividing the cumulative reference value $E R_{R}$ with the cumulative reference value $\mathrm{ER}_{\mathrm{C}}$.

\subsection{Diurnal emission patterns}

To test if the diurnal cycles in VOC emissions for mature and developing Scots pine shoots are equal, we calculated the average diurnal cycles in VOC emissions for mature and developing Scots pine shoots. Data from all 3 years were included 

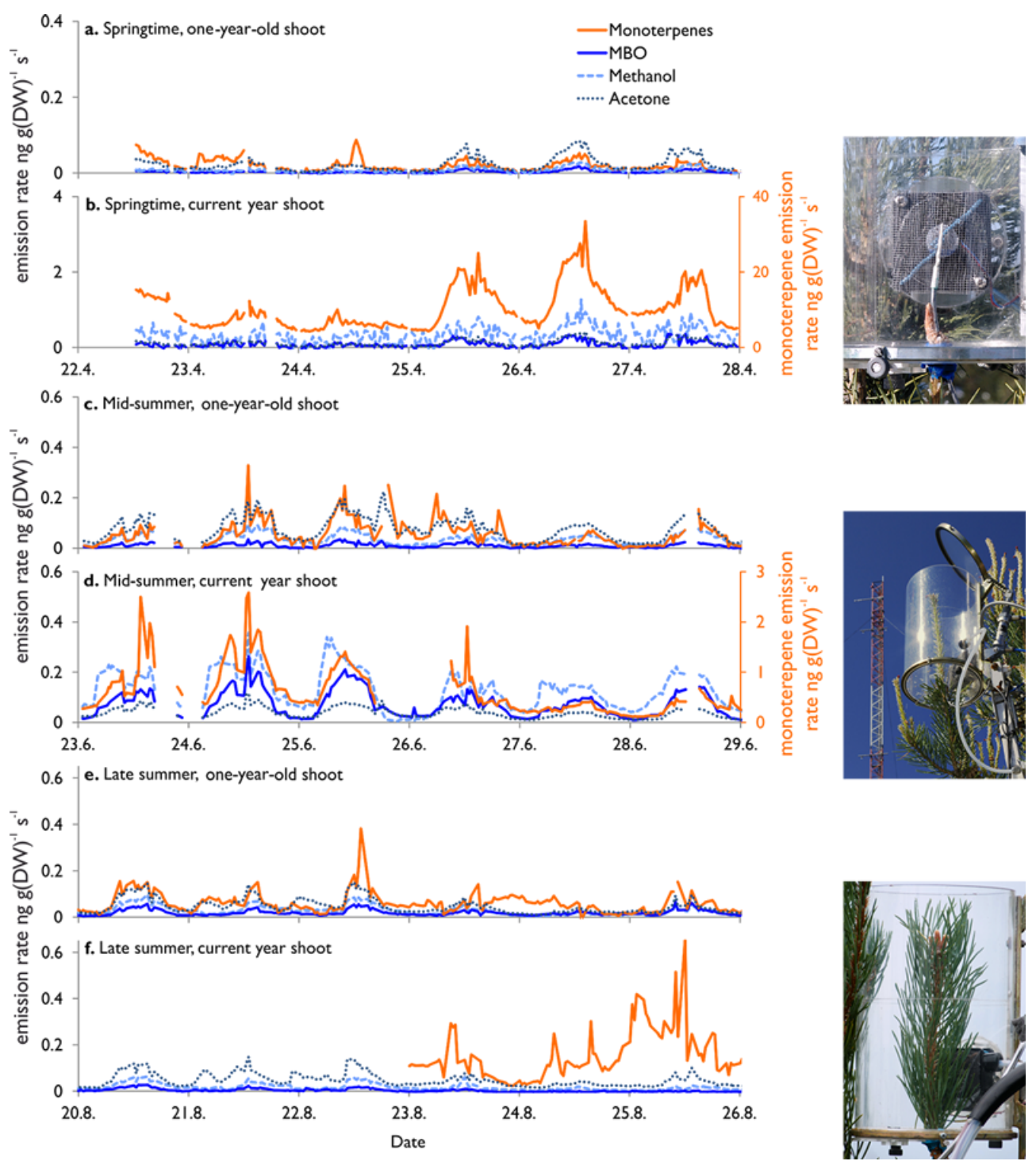

Fig. 2. Monoterpene, $\mathrm{MBO}$ and methanol emission rates from developing and mature Scots pine shoots. (a, b) 22-27 April 2010, during the dormancy break, before any growth commences. (c, d) 22-28 June 2010, during the most intensive needle elongation period. (e, f) 20-25 August 2010 when the shoot length growth has ended. NOTE: In panels (b) and (d), monoterpene emission rates of the current year bud/shoot are given in the right $y$ axis due to magnitude differences in emission rates. Next to panels (b), (d) and (f) photos from the corresponding stage of shoot development.

and three periods differing in the growth stage of needles and shoots were chosen for comparisons: (i) April (before the growth onset), (ii) the most intensive needle elongation days (needle elongation rate $\geq 0.5 \mathrm{~mm} \mathrm{~d}^{-1}$ ), and (iii) September (after the end of growth). The emission rates during each 3hour measurement cycle (eight per day) were averaged, and only days with all 3 -hour cycles with data coverage $50 \%$ or higher were accepted.

The diurnal emission data was normalized using the daily means to enable the comparison of the emission rates for days having unequal environmental conditions. For each compound, we separately tested if the diurnal pattern of emissions between developing and mature shoots during each specified period of growth stage was significantly different using a $t$ test $(p \leq 0.05)$. The chamber temperatures were tested in the same way, in order to analyze the possible differences in diurnal temperature dynamics in the chambers. Depending on the compound, the number of days with sufficient data for April, maximum growth period and September was $20-47,35-67$ and 15-39 in April, respectively. 
Table 1. The ratio between the VOC emission rate of the growing needles to the emission rate of mature needles (unitless), obtained by dividing the daily average emission rate of growing needles with the daily average emission rate of mature needles. The medians represent data from all three measurement years, and the periods cover April, the most intensive needle elongation days (needle elongation rate $\geq 0.5 \mathrm{~mm} \mathrm{~d}^{-1}$, in June and July), and September.

\begin{tabular}{llcccc}
\hline & & Methanol & Acetone & MBO & Monoterpenes \\
\hline \multirow{2}{*}{ April } & Upper quartile & 39 & 42 & 23 & 770 \\
& Median & 25 & 29 & 18 & 520 \\
& Lower quartile & 11 & 19 & 10 & 260 \\
\hline Intensive needle & Upper quartile & 4.2 & 3.3 & 6.5 & 30 \\
elongation & Median & 2.4 & 1.8 & 3.5 & 3.5 \\
& Lower quartile & 1.3 & 1.1 & 2.8 & 0.3 \\
\hline \multirow{2}{*}{ September } & Upper quartile & 0.8 & 1.0 & 0.5 & 1.2 \\
& Median & 0.5 & 0.8 & 0.4 & 0.5 \\
& Lower quartile & 0.2 & 0.6 & 0.2 & 0.2 \\
\hline
\end{tabular}

\section{Results and discussion}

\subsection{The developing buds and needles as sources for volatiles}

Growing leaves have previously been observed to release significantly more methanol than mature tissues (e.g., McDonald and Fall 1993; Galbally and Kirstine, 2002; Hüve et al., 2007) due to cell wall demethylation during cell growth, and this was confirmed in our study as well. In addition to methanol, the initial phases of new biomass development dramatically influence the $\mathrm{MBO}$ and monoterpene emissions as well, which is in line with the results of Hakola et al. (2006). The Scots pine buds became strong sources of monoterpenes, MBO, methanol and acetone well before any measurable growth (Fig. 2a, b; Table 1). This pattern was consistent over the 3 -year measurement period. The monoterpene emissions per unit biomass were two orders of magnitude higher for the developing shoot than for the mature, 1 to 2-year-old foliage in the spring, and remained at a higher level until the growth ended in late summer. The bud and developing shoot were also strong sources of MBO, methanol and acetone (Fig. 2a-d).

The monoterpene emissions from conifer tissues can originate either from preformed storage or from de novo synthesis. In mature Scots pine needles, Ghirardo et al. (2010) estimated that ca. $40 \%$ of the emissions originated from the storage pool, but in buds or developing needles such estimates have not been reported. Furthermore, only very few data exist on the monoterpene contents in buds. In one study in North America, the monoterpene concentration in apical buds of two pine species was $10-18 \mathrm{mg} \mathrm{g}(\mathrm{DW})^{-1}$ (Hall et al., 2013), comparable to the mature needles of the same species. Although the Scots pine buds most likely also contain significant constitutive monoterpene storage, it is unlikely that the observed, extremely high emission rates would originate solely from preformed storages. If the emissions had been released only from storage, then the buds and mature needles should have shown similar magnitude of emission rates in identical conditions in spring. This was, however, not the case. Furthermore, there are no permanent storage pools for $\mathrm{MBO}$ or methanol in plant tissues. We therefore suggest that the reason for the extremely high monoterpene, MBO and methanol emission rates is the high metabolic activity in the quiescent and growing tissues (buds and developing shoots), resulting in de novo synthesis.

The availabilities of energy and carbon skeletons are the most important factors in production of VOCs in cells. Additionally, emissions of many volatile compounds are strongly correlated with corresponding enzyme activities, indicating transcriptional, post-transcriptional and enzymatic controls (Fischbach et al., 2002, Laothawornkitkul et al., 2009, Dudareva et al., 2013). The measured VOCs (terpenoids, methanol and acetone) originate from several different biosynthetic pathways, and it is ambiguous if the physiological controls of all these pathways are coordinated. However, it seems that they are all activated during the new biomass growth period. Owen and Peñuelas (2005) suggested that the volatile terpenoid emissions might be controlled by the same factors that control the terpenoid pathway, producing the higher molecular weight, "essential" terpenoids (Lichtenthaler 1999). These include e.g., carotenoid pigments and gibberellins, the plant hormones regulating many developmental processes, and in particular cell division and shoot elongation. Thus, it is not surprising to also see high production of volatile terpenoids at the time when the growth hormone production is highest.

The cellular processes involved in the sustained, rather high emission of acetone are still ambiguous, although it is one of the most abundant compounds in e.g., Scots pine and Norway spruce emissions (Janson and de Serves, 2001). Acetone is not stored in plant tissues and its production has been linked to wounding, deterring herbivores, rapid light-dark 

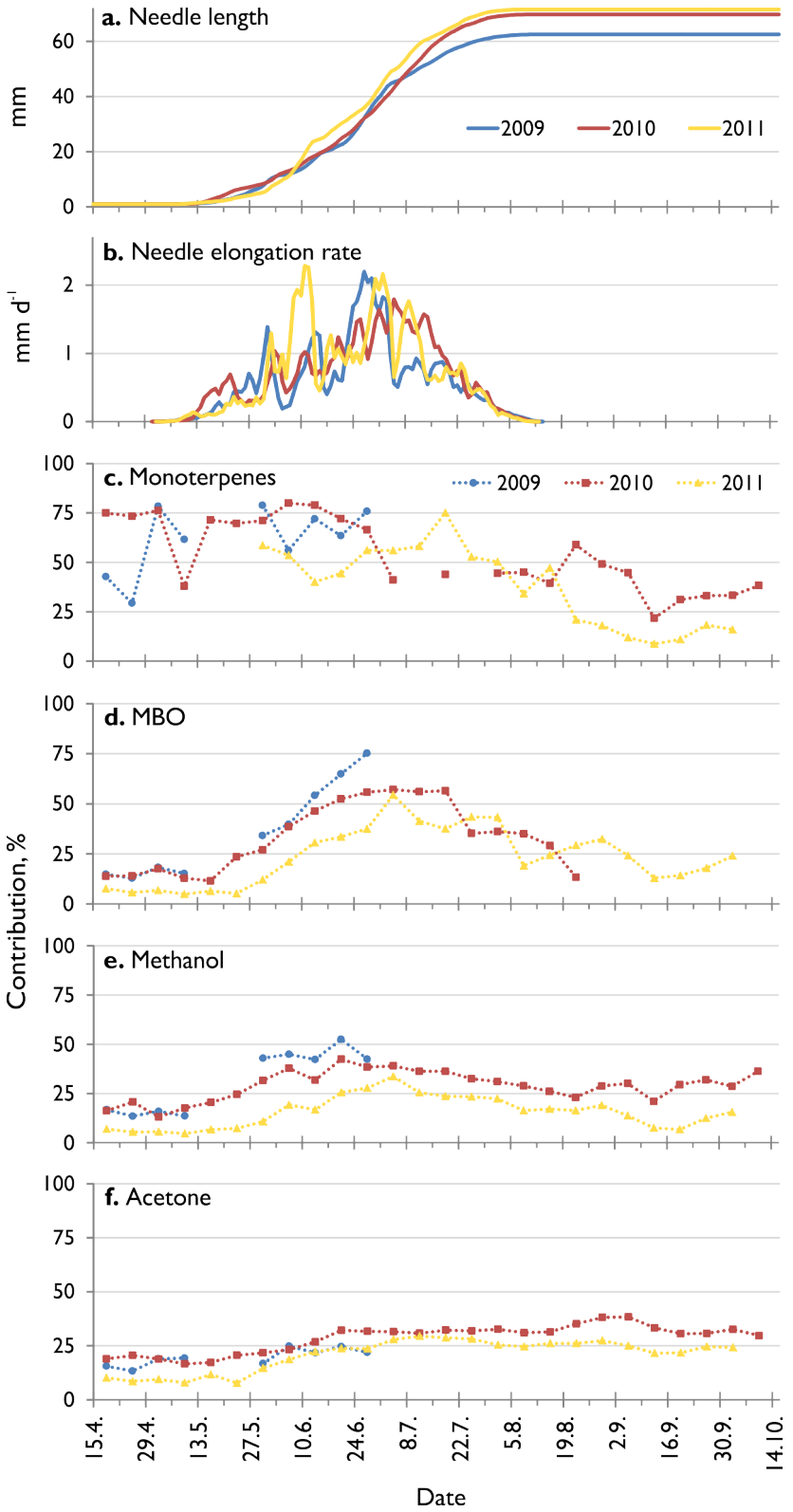

Fig. 3. The growth of needles and the relative contribution of developing shoots to the emissions of the whole foliage. The points represent one week averages in 3 consecutive years (2009-2011). (a) length of growing needles; (b) elongation rate of growing needles. The contribution of developing needle age class to canopy emissions of (c) monoterpenes, (d) MBO, (e) methanol, and (f) acetone.

transitions or anoxic conditions in roots (Fall, 2003; Seco et al., 2007).

Our results show that although the new shoots make up only a small biomass in the beginning of the growth period (Fig. 3a), their contribution to the emissions of the whole foliage is large (Fig. 3c-f). To estimate the contributions of growing vs. mature shoots to canopy emissions, we approximated their relative contributions using a model for needle and shoot. This is most clearly seen in monoterpene emissions, where the buds are the dominating source (30-75\%) in the canopy before the bud break. The contribution of buds is lower for other compounds, but nevertheless they are important sources of $\mathrm{MBO}$, methanol and acetone in the spring as well. During the most intensive needle elongation period in June and July (Fig. 3b), the elongating needles are a strong source of methanol, acetone, MBO and monoterpenes, and contribute about half or one-third of the emissions from Scots pine foliage (Fig.3c-f). Only when both the shoots and needles are fully grown in early August, is the contribution of current year needles to the emissions for the whole foliage approximately equal with mature shoots (Table 1).

The large monoterpene emissions from buds imply that the growing foliage is a significant source for aerosol precursors in spring, which has never been shown. Based on our results, if the emissions in spring and early summer are estimated based on old foliage alone, the annual cumulative monoterpene emissions from the pine stand are only $50 \%$ of that when the growing foliar biomass is taken into account. Further, when shorter periods are investigated the difference between the two estimates becomes significantly higher, especially during the most intensive new shoot and needle biomass growth. By the end of thermal growing season (in the middle of October) the cumulative "concealed" proportion of emissions - that is, the emissions that are not taken into account, compared to the assumption that all needles are emitting like that of mature needles - is on average $11 \%$ for methanol, $21 \%$ for acetone, $28 \%$ for $\mathrm{MBO}$ and $98 \%$ for monoterpenes (Table 2). Moreover, if only the first half of the growing season is taken into account - the period from the end of April to the end of June - the corresponding cumulative missing emissions are $29 \%, 45 \%, 50 \%$ and $200 \%$, respectively.

In boreal evergreen conifers with a single flush per year, such as in Scots pine, the new foliage growth is characterized by a rather short and intensive shoot and needle elongation period (Fig. 4). However, in many other ecosystems, both evergreen and deciduous tree species can have several flushes (e.g., loblolly pine, longleaf pine, red oak), or are freely flushing (e.g., many birches, elms and poplars), and thus these species and ecosystems may have several highemission periods in a growing season. More importantly, many of these species (e.g., many oaks and pines) have extremely high isoprene or monoterpene emission potentials (Hewitt et al., 1999). If the control of emissions in growing biomass is closely related to cell growth processes, then the ecosystem-scale emissions in areas (e.g., mid-latitudes or in tropical regions), with more or less constantly growing foliage, may reflect the growth-induced isoprene emissions rather than the normal light- and temperature-dependent emissions.

While the characterization of vegetation types in the widely used global emission models (Guenther et al., 1995; Naik et al., 2004; Lathiere et al., 2006; Guenther et al., 2012) 
Table 2. The proportion (\%) of the concealed emissions from canopy if the effect of growing Scots pine needle biomass on VOC emissions is not taken into account. $0 \%$ indicates no effect of the growing biomass on emissions; $100 \%$ indicates an equal emission from growing and mature needles; and $>100 \%$ a greater effect of growing biomass than the mature foliage on total canopy emissions. Average $+10 \%$ and average $-10 \%$ represent modified calculations where the proportion of growing needles has been increased or decreased by $10 \%$, respectively. The periods represent the first half of and the whole thermal growing season (daily mean temperature permanently $>5^{\circ} \mathrm{C}$ ).

\begin{tabular}{llllll}
\hline & & Methanol & Acetone & MBO & Monoterpenes \\
\hline April-midsummer & Max & 31 & 60 & 176 & 368 \\
& Average $+10 \%$ & 31 & 46 & 52 & 211 \\
& Average & 29 & 45 & 50 & 200 \\
& Average $-10 \%$ & 25 & 43 & 46 & 182 \\
& Min & 22 & 32 & 22 & 149 \\
\hline \multirow{2}{*}{ Thermal growing } & Max & 16 & 60 & 43 & 158 \\
& Average $+10 \%$ & 12 & 23 & 30 & 103 \\
& Average & 11 & 21 & 28 & 98 \\
& Average $-10 \%$ & 8 & 19 & 24 & 87 \\
& Min & 2 & 18 & 22 & 78 \\
\hline
\end{tabular}
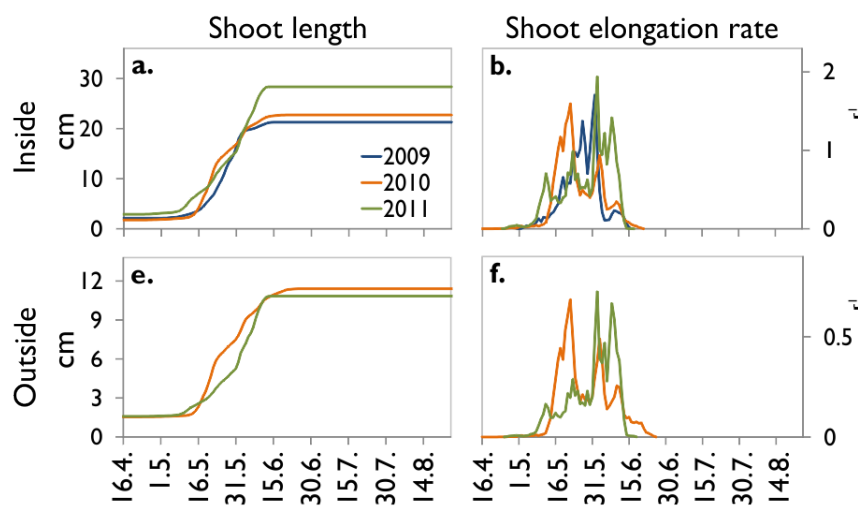
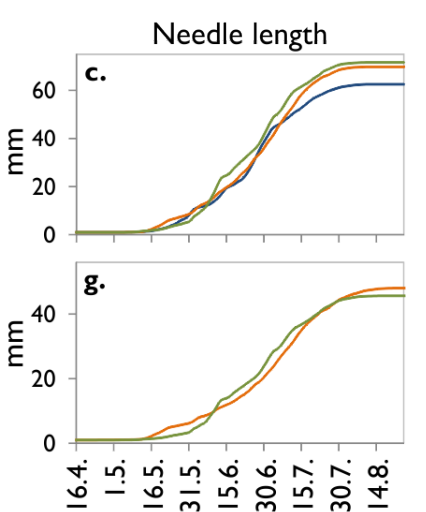

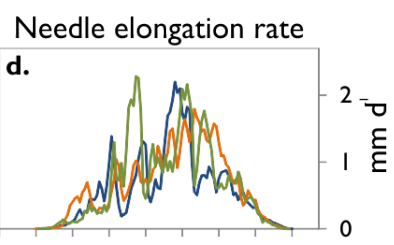

h.

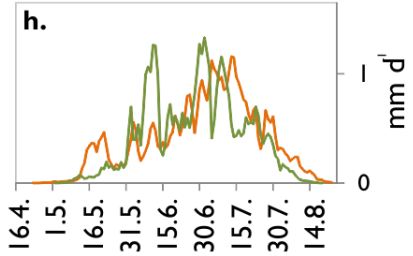

Date

Fig. 4. The shoot and needle lengths and elongation rates during growing seasons 2009-2011. (a-d) inside, (e-h) outside the shoot enclosure. The needle and shoot elongation outside the enclosure was not measured during the growing season 2009.

does not include any speciation between the shoot growth patterns, these models are missing such large endogenous variations in emission rates. Thus the model approaches using light and temperature as drivers for emissions may or may not agree well with measurements, but the underlying biological processes are not captured with the use of these environmental drivers only. Most global monoterpene and isoprene emission estimates are derived either by scaling up the leaf-level responses to ecosystem types, or by simulating vegetation with a dynamic vegetation model, and attributing the variations in emissions only to changes in the amount of emitting leaf biomass, neglecting to account for variations in emission strength with leaf age (Guenther et al., 2006; Monson et al., 2012; Oderbolz et al., 2013). Furthermore, in the most advanced leaf-algorithm the change in emission rate with leaf age has only been taken into account as fractional adjustments embedded in the "Leaf age emission activity fac- tor" (Guenther et al., 2012), without a defined physiological basis for the change in the activity factor over seasons.

Measuring reactive gases in field conditions is challenging. The accuracy of a dynamic enclosure system was determined by Kolari et al. (2012) to be in the range of 5-30\%, and thus the values obtained with such a system may be slightly lower than the actual emission rates. The accuracy should, however, not be different between bud and mature shoot enclosures having similar measurement setups. The enclosure systems evidently cause higher temperatures, affecting growth inside the enclosures, and thus direct comparisons with shoots growing in the open air may be biased. In order to analyze the effect of enclosure environment on growth, we measured the shoot and needle elongation both inside and outside of the enclosure. Inside the enclosure, the onset of shoot elongation took place during the last 2 weeks of April in all years (Fig. 4a, b) and the shoot elongation 


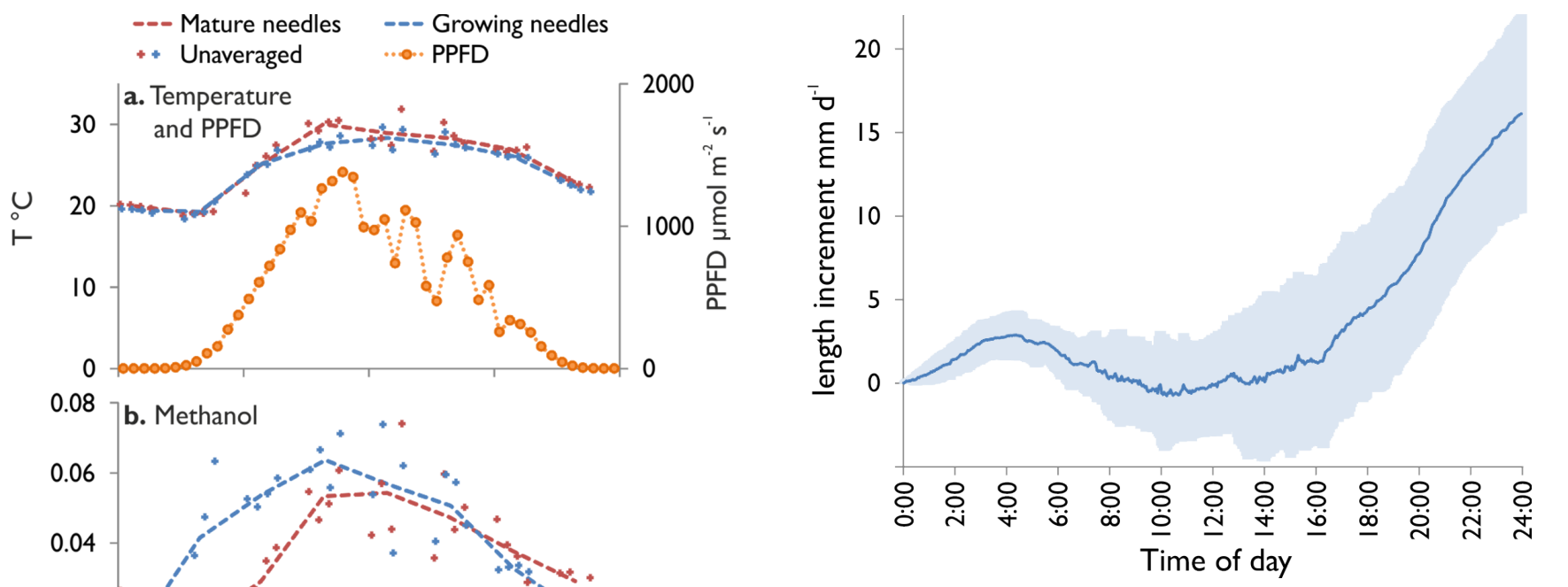

Fig. 6. The measured average shoot length increment diurnal pattern of a Scots pine shoot outside the enclosure under unshaded conditions during 12 days, with moderate elongation rate in summers 2010 and 2011. The shoot length at the beginning of day is set to 0 . The shaded area represents \pm 1 standard deviation in shoot elongation.

ended in the middle of June. The onset of needle elongation inside the enclosure (Fig. 4c, d) took place from a couple of days to 2 weeks later than that of shoot elongation, and continued until mid-August. Outside the enclosure (Fig. 4eh) the growth onset occurred practically at the same time, but both the shoot and needles reached their full length 2-14 days later than inside. Also, although the shoot and needle growth rates closely resembled each other, their actual growth rates were different. The elongation rates inside the enclosure were about twofold compared with the elongation rates outside the chamber, most likely due to the more favorable conditions inside the enclosure. However, since the above-reported emission rates are calculated based on actual leaf mass or area of the enclosed shoot, the incident growth rates do not affect our main results. The enclosure temperature may naturally affect the VOC emission rates from tissues due to the effect on volatilization. This effect should be of similar magnitude for both mature and growing shoots, and thus its influence on the relative emission rates is insignificant.

\section{Diurnal emission patterns}

Fig. 5. The diurnal pattern in VOC emission rates from a mature and a developing Scots pine shoot on 8 July 2011. (a) Temperature inside enclosure and photosynthetic photon flux density. (b-e) Emission rates of different compounds. Crosses represent individual measurements, and dashed lines are 3-hour averages. 
—Growing needles - Mature needles

April The days when needle

Methanol

a

2

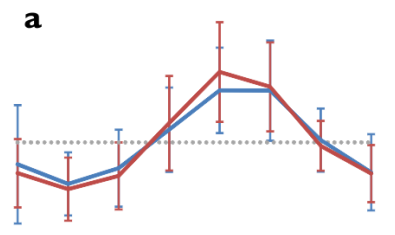

0
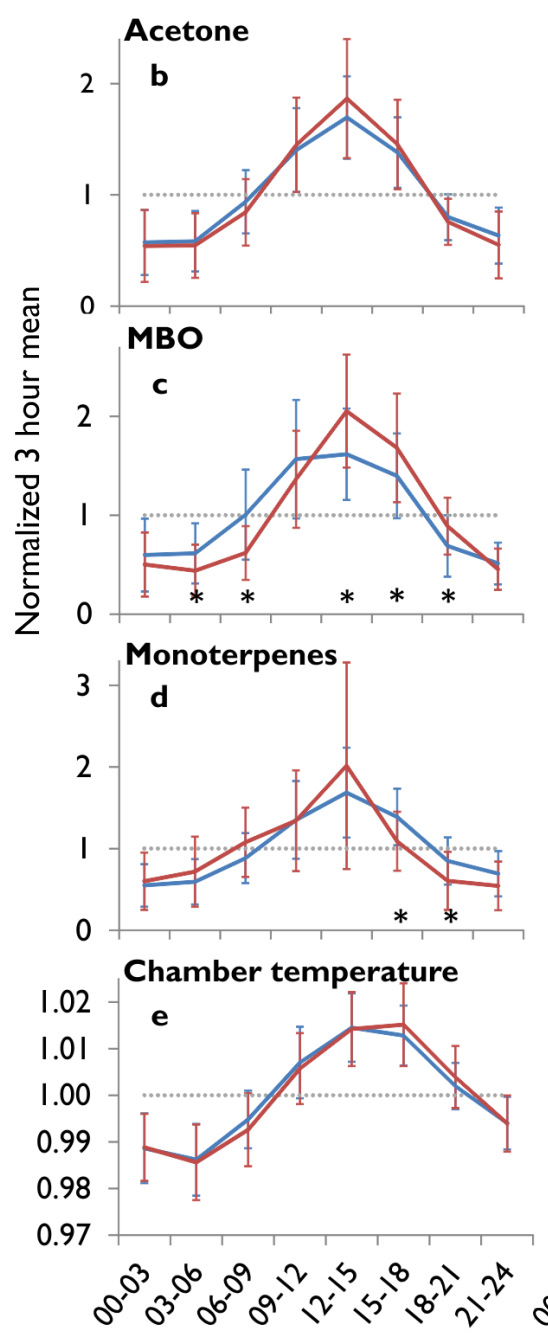

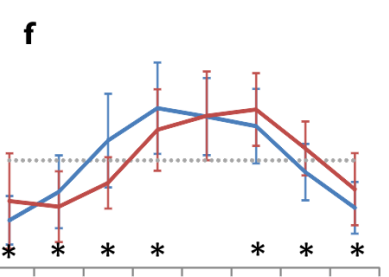

g

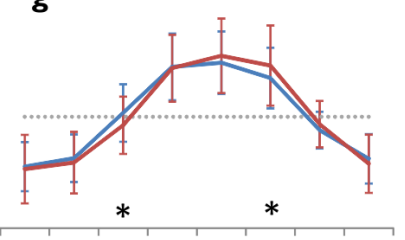

h

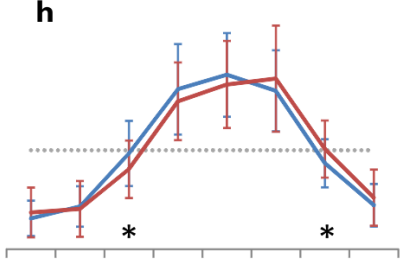

i

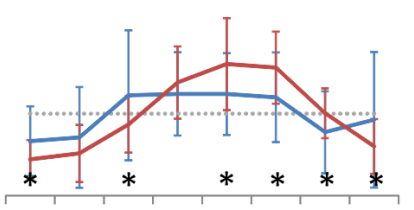

\section{j}

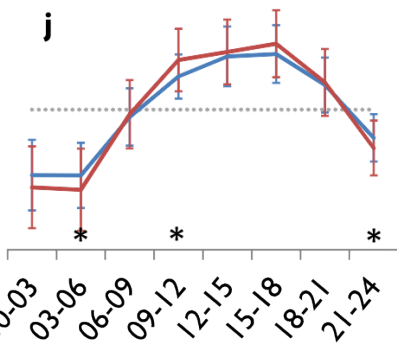

September
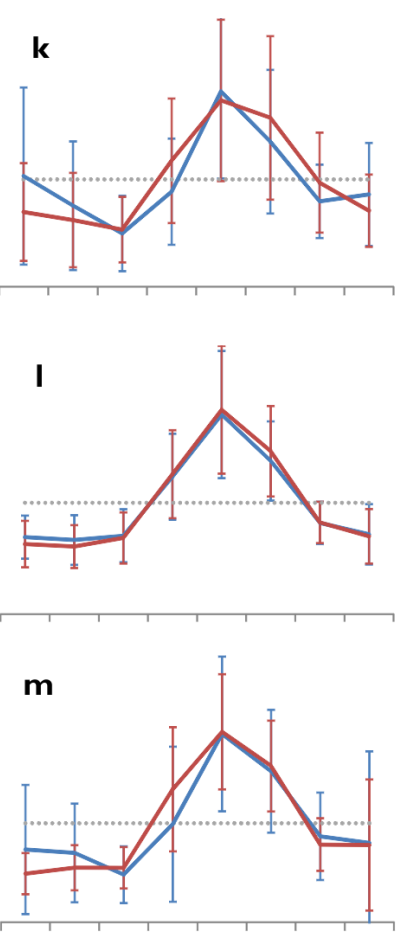

n

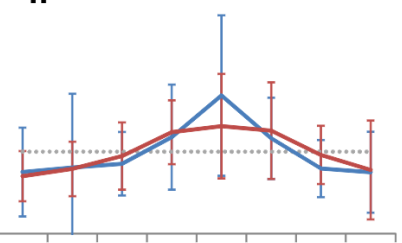

o

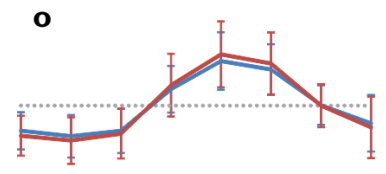

Time of Day

Fig. 7. The average diurnal cycle in VOC emissions from mature and developing Scots pine shoots in April before the onset of shoot growth (a-d), during the most intensive needle elongation days (needle elongation $\geq 0.5 \mathrm{~mm} \mathrm{~d}^{-1}$, (f-i)) and in September when growth has ended (k-n). The $y$ axis values are the 3-hour average emission rates normalized to the average of each day. The grey dashed lines show the normalized daily averages $(=1)$. The error bars equal $\pm 1 \mathrm{SD}$. The stars show statistically significant differences $(t$ test, $p \leq 0.05)$ in the normalized emissions between the developing and the mature shoot. The data is for the years $2009-2011$ ( $n=11-67$ days, mostly $>30$ days). The three figures on the bottom (e, $\mathbf{j}$ and $\mathbf{o})$ show the normalized average diurnal cycles in chamber temperatures during the corresponding days, calculated from the temperatures in Kelvin scale. 
emissions of the water-soluble methanol for foliage, so that emissions typically show a pronounced burst when stomata open in the morning (e.g., Niinemets and Reichstein, 2003; Huve et al., 2007). The less water-soluble isoprenoids are not as much controlled by stomatal actions, and their emission rates follow light and temperature, influencing production and volatilization, respectively. Like seasonal emission patterns, the diurnal patterns have previously only been studied in fully expanded leaves, and thus it is unknown how growth processes may influence the emission dynamics during the course of a day.

Our measurements showed that during the most intensive elongation period, the Scots pine shoots grew during most of the day, but a pause or even mild shrinking was observed during the early morning hours (Fig. 6), potentially due to hydraulic limitations developing during the leaf development (Pantin et al., 2011). This also had a clear effect on the diurnal pattern of emissions during the needle elongation period (Figs. 5, 7). Before and after the growth period (Fig. 7a-d and $\mathrm{k}-\mathrm{n}$ ) the average diurnal emission patterns and the daytime maxima were fairly similar in both mature and developing shoots, and the maximum emissions typically coincided with the daytime maximum temperatures. However, during the most intensive growth (Fig. 7f-i) the methanol, MBO and monoterpene emissions from growing shoots increased earlier in the morning, and reached the maximum emission rates earlier than emissions from the mature shoots. The difference in acetone emissions between growing and mature shoots was not as clear. Most importantly, the diurnal emission pattern of developing shoots did not match with the variations in temperature (Fig. 7j), contrary to that in mature shoots. After the maturation of needles in August, the diurnal emission patterns between young and mature shoots did not differ from each other anymore (Fig. $7 \mathrm{k}-\mathrm{n}$ ), These results imply that there are other, more important drivers of emissions in growing shoots than temperature.

The diurnal pattern of terpenoid or other VOC biosynthesis has not been studied in detail, although reports on emission variations over the day abound. The observed differences in diurnal patterns of emissions from growing and mature needles suggests that during the period of high metabolic activity, the biosynthesis of methanol, MBO and monoterpenes is indeed linked to the up-regulation of the respective pathways, and a potential circadian regulation of biosynthesis has been suggested (Laothawornkitkul et al., 2009).

Our results on the diurnal emission patterns are in line with Hewitt et al. (2011), who used micrometeorological methods in a tropical oil palm plantation and rain forest, and found that isoprene emission potential had a very clear diurnal cycle, with low nighttime and high daytime values with a maximum well before midday, contrary to the ambient temperature which reached the maximum somewhat later in the day. Isoprene is not stored in plant tissues, and therefore the biosynthesis also was most active in the morning hours. Our findings shed light on the results of Hewitt et al. (2011), pro- viding a possible explanation for the high emission potential before noon.

\section{Conclusions}

In this study, we showed that the growing Scots pine shoots emit considerable amounts of volatile organic compounds. The needle elongation rate as well as timing of elongation correlated with the large VOC emissions, suggesting that growth processes and high emissions potentially have a causal relationship. This relationship, and the divergence between the diurnal cycles in emissions from mature and growing needles, indicate that existing model approaches using only light and temperature as direct drivers for emissions should be modified to capture the effect of growing foliar biomass on emissions. As the climate-change-induced lengthening of growing seasons will most likely advance the timing of bud burst, the uncertainties in seasonal emission estimates related to plant growth may become even more important in the coming decades.

Based on our results, a refined, mechanistic description for emission processes during the new foliage biomass growth, as well as a more detailed description of the characteristic growth patterns for the different plant functional types should be implemented into emission models. In ecosystems where the timing of new foliar biomass differs from that found in boreal evergreen forests - where new needles grow within a time frame of about 100 days - the effect of foliar biomass growth on VOC emissions is not necessarily confined to spring and early summer only. This calls upon a new generation of emission models, based on functions describing the drivers for key metabolic processes, and testing them under field conditions with data sets of sufficiently high temporal resolution.

Our results bring new insights to the consequences of seasonality of biosphere activity and on the temporal variations in sources of aerosol precursor in forested ecosystems. We showed that during the three-four spring and summer months, the monoterpene, methanol and $\mathrm{MBO}$ emissions are dominated by the new foliage growth. This may have considerable impact on the frequent springtime new particle formation events in boreal and temperate forests (Dal Maso et al., 2005; Manninen et al., 2010). 
Acknowledgements. This work was funded by the Academy of Finland Centre of Excellence program (grant no. 1118615), the Graduate school "Atmospheric Composition and Climate Change: From Molecular Processes to Global Observations and Models Doctoral Programme (ACCC)", the European Research Council Project (grant no. 227463-ATMNUCLE), and the Nordic Center of Excellence CRAICC. The authors acknowledge the SMEAR II station and the Hyytiälä Forest Research Station personnel for practical assistance.

Edited by: S. M. Noe

\section{References}

Altimir, N., Vesala, T., Keronen, P., Kulmala, M., and Hari, P.: Methodology for direct field measurements of ozone flux to foliage with shoot chambers, Atmos. Environ. 36, 19-29, 2002.

Arneth, A., Monson, R. K., Schurgers, G., Niinemets, Ü., and Palmer, P. I.: Why are estimates of global terrestrial isoprene emissions so similar (and why is this not so for monoterpenes)?, Atmos. Chem. Phys., 8, 4605-4620, doi:10.5194/acp-8-46052008, 2008.

Bourtsoukidis, E., Bonn, B., Dittmann, A., Hakola, H., Hellén, H., and Jacobi, S.: Ozone stress as a driving force of sesquiterpene emissions: a suggested parameterisation, Biogeosciences, 9, 4337-4352, doi:10.5194/bg-9-4337-2012, 2012.

Bäck, J., Aalto, J., Henriksson, M., Hakola, H., He, Q., and Boy, M.: Chemodiversity of a Scots pine stand and implications for terpene air concentrations, Biogeosciences, 9, 689-702, doi:10.5194/bg-9-689-2012, 2012.

Dal Maso, M., Kulmala, M., Riipinen, I., Wagner, R., Hussein, T., Aalto, P., and Lehtinen, K. E. J.: Formation and growth of fresh atmospheric aerosols: eight years of aerosol size distribution data from SMEAR II, Hyytiälä, Finland, Boreal Env. Res. 10, 323336, 2005.

de Gouw, J. and Warneke, C.: Measurements of volatile organic compounds in the Earth's atmosphere using proton-transferreaction mass spectrometry, Mass Spectrom. Rev. 26, 223-257, 2007.

Dudareva, N., Klempien, A., Muhlemann, J. K., and Kaplan, I.: Biosynthesis, function and metabolic engineering of plant volatile organic compounds, New Phytol., 198, 16-32, 2013.

Fall, R.: Abundant oxygenates in the atmosphere: a biochemical perspective, Chem. Rev., 103, 4941-4952, 2003.

Fall, R., Karl, T., Jordan, A., and Lindinger, W.: Biogenic C5 VOCs: release from leaves after freeze-thaw wounding and occurrence in air at a high mountain observatory, Atmos. Environ. 35, 39053916, 2001.

Fischbach, R. J., Staudt, M., Zimmer, I, Rambal, S., and Schnitzler, J.-P.: Seasonal pattern of monoterpene synthase activities in leaves of the evergreen tree Quercus ilex, Physiol. Plantarum., 114, 354-360, 2002.

Galbally, I. E. and Kirstine, W.: The production of methanol by flowering plants and the global cycle of methanol, J. Geophys. Res., 99, 12773-12792, 2002.

Geron, C. D. and Arnts, R. R.: Seasonal monoterpene and sesquiterpene emissions from Pinus taeda and Pinus virginiana, Atmos. Environ., 44, 4240-4251, 2010.
Ghirardo, A., Koch, K., Taipale, R., Zimmer, I., Schnitzler, J.-P., and Rinne, J.: Determination of de novo and pool emissions of terpenes from four common boreal/alpine trees by $13 \mathrm{CO} 2$ labelling and PTR-MS analysis, Plant Cell Environ., 33, 781-792, 2010.

Gray, D. W., Goldstein, A. H., and Lerdau, M. T.: Thermal history regulates methylbutenol basal emission rate in Pinus ponderosa, Plant Cell Environ., 29, 1298-1308, doi:10.1111/j.13653040.2006.01508.x, 2006.

Grote, R. and Niinemets, Ü. Modeling volatile isoprenoid emissions - a story with split ends, Plant Biol., 10, 8-28, 2008.

Guenther, A., Zimmerman, P., Harley, P., Monson, R., and Fall, R.: Isoprene and monoterpene emission rate variability: model evaluation and sensitivity analysis, J. Geophys. Res., 98D, 1260912617, 1993.

Guenther, A., Hewitt, C. N., Erickson, D., Fall, R., Geron, C., Graedel, T., Harley, P., Klinger, L., Lerdau, M., McKay, W. A., Pierce, T., Scholes, B., Steinbrecher, R., Tallamraju, R., Taylor, J., and Zimmerman, P.: A global model of natural volatile organic compound emissions, J. Geophys. Res., 100, 8873-8892, 1995.

Guenther, A., Karl, T., Harley, P., Wiedinmyer, C., Palmer, P. I., and Geron, C.: Estimates of global terrestrial isoprene emissions using MEGAN (Model of Emissions of Gases and Aerosols from Nature), Atmos. Chem. Phys., 6, 3181-3210, doi:10.5194/acp-63181-2006, 2006.

Guenther, A., Jiang, X., Heald, C. L., Sakulyanonvittaya, T., Duhl, T., Emmons, L. K., and Wang, X.: The Model of Emissions of Gases and Aerosols from Nature version 2.1 (MEGAN2.1): an extended and updated framework for modeling biogenic emissions, Geosci. Model Dev., 5, 1471-1492, 2012.

Hakola, H., Tarvainen, V., Bäck, J., Ranta, H., Bonn, B., Rinne, J., and Kulmala, M.: Seasonal variation of mono- and sesquiterpene emission rates of Scots pine, Biogeosciences, 3, 93-101, doi:10.5194/bg-3-93-2006, 2006.

Hall, D. E., Yuen, M. M. S., Jancsik, S., Quesada, A. L., Dullat, H. K., Li, M., Henderson, H., Arango-Velez, A., Liao, N. Y., Docking, R. T., Chan, S. K., Cooke, J. E. K., Breuil, C., Jones, S. J. M., Keeling, C. I., and Bohlmann, J.: Transcriptome resources and functional characterization of monoterpene synthases for two host species of the mountain pine beetle, lodgepole pine (Pinus contorta) and jack pine (Pinus banksiana), BMC Plant Biol., 13, 80, doi:10.1186/1471-2229-13-80, 2013.

Hari, P. and Kulmala, M.: Station for measuring ecosystematmosphere relations (SMEAR II), Boreal Environ. Res., 10, 315-322, 2005.

Heide, O. M.: Dormancy release in beech buds (Fagus sylvatica) requires both chilling and long days, Physiol. Plantarum, 89, 187191, 1993.

Hewitt, C. N., Street, R., Scholefield, P., and Stewart, H.: Isoprenoid emission potential database, http://www.es.lancs.ac.uk/ cnhgroup/iso-emissions.pdf, 1999.

Hewitt, C. N., Ashworth, K., Boynard, A., Guenther, A., Langford, B., MacKenzie, A. R., Misztal, P. K., Nemitz, E., Owen, S. M., Possell, M., Pugh, T. A. M., Ryan, A. C., and Wild, O.: Ground-level ozone influenced by circadian control of isoprene emissions, Nat. Geosci., 4, 671-674, 2011.

Hüve, K., Christ, M. M., Kleist, E., Uerlings, R., Niinemets, Ü, Walter, A., and Wildt, J.: Simultaneous growth and emission measurements demonstrate an interactive control of methanol re- 
lease by leaf expansion and stomata, J. Exp. Bot., 58, 1783-1793, 2007.

Hänninen, H., Slaney, M., and Linder, S.: Dormancy release of Norway spruce under climatic warming: testing ecophysiological models of bud burst with a whole-tree chamber experiment, Tree Physiol., 27, 291-300, 2007.

Janson, R. and de Serves, C.: Acetone and monoterpene emissions from the boreal forest in northern Europe, Atmos. Environ., 35, 4629-4637, 2001.

Karl, T., Guenther, A., Spirig, C., Hansel, A., and Fall, R.: Seasonal variation of biogenic VOC emissions above a mixed hardwood forest in northern Michigan, Geophys. Res. Lett., 30, 23, doi:10.1029/2003GL018432, 2003.

Kesselmeier, J. and Staudt, M.: Biogenic Volatile Organic Compounds (VOC): An Overview on Emission, Physiol. Ecol., J. Atmos. Chem, 33, 23-88, 1999.

Kolari, P., Bäck, J., Taipale, R., Ruuskanen, T. M., Kajos, M. K., Rinne, J., Kulmala, M., and Hari, P.: Evaluation of accuracy in measurements of VOC emissions with dynamic chamber system, Atmos. Environ., 62, 344-351, 2012.

Komenda, M. and Koppman, R.: Monoterpene emissions from Scots pine (Pinus sylvestris): Field studies of emission rate variabilities, J. Geophys. Res., 107, D13, 4161, doi:10.1029/2001JD000691, 2002.

Kulmala, M., Kontkanen, J., Junninen, H., Lehtipalo, K., Manninen, H. E., Nieminen, T., Petäjä, T., Sipilä, M., Schobesberger, S., Rantala, P., Franchin, A., Jokinen, T., Järvinen, E., Äijälä, M., Kangasluoma, J., Hakala, J., Aalto, P. P., Paasonen, P., Mikkilä, J., Vanhanen, J., Aalto, J., Hakola, H., Makkonen, U., Ruuskanen, T., Mauldin, L. R. III, Duplissy, J., Vehkamäki, H., Bäck, J., Kortelainen, A., Riipinen, I., Kúrten, T., Johnston, M. V., Smith, J. N., Ehn, M., Mentel, T. F., Lehtinen, K. E. J., Laaksonen, A., Kerminen, V.-M., and Worsnop, D. R.: Direct observations of atmospheric nucleation, Science, 339, 943-946, doi:10.1126/science.1227385, 2013.

Laothawornkitkul, J., Taylor, J. E., Paul, N. D., and Hewitt, C. N.: Biogenic volatile organic compounds in the Earth system, New Phytol., 183, 27-51, 2009.

Lappalainen, H. K., Sevanto, S., Dal Maso, M., Taipale, R., Kajos, M., Kolari, P., and Bäck, J.: A source-orientated approach for estimating daytime concentrations of biogenic volatile organic compounds in an upper layer of a boreal forest canopy, Boreal Environ. Res., 18, 127-144, 2013.

Lathière, J., Hauglustaine, D. A., Friend, A. D., De NobletDucoudré, N., Viovy, N., and Folberth, G. A.: Impact of climate variability and land use changes on global biogenic volatile organic compound emissions, Atmos. Chem. Phys., 6, 2129-2146, doi:10.5194/acp-6-2129-2006, 2006.

Lichtenthaler, H. K.: The 1-deoxy-D-xylulose-5-phosphate pathway of isoprenoid biosynthesis in plants, Annu. Rev. Plant Physiol. Plant Mol. Biol., 50, 47-65, 1999.

MacDonald, R. C. and Fall R.: Detection of substantial emissions of methanol from plants to the atmosphere, Atmos. Environ., 27A, 1709-1713, 1993.

Manninen, H. E., Nieminen, T., Asmi, E., Gagné, S., Häkkinen, S., Lehtipalo, K., Aalto, P., Vana, M., Mirme, A., Mirme, S., Hõrrak, U., Plass-Dülmer, C., Stange, G., Kiss, G., Hoffer, A., Töő, N., Moerman, M., Henzing, B., de Leeuw, G., Brinkenberg, M., Kouvarakis, G. N., Bougiatioti, A., Mihalopoulos, N.,
O'Dowd, C., Ceburnis, D., Arneth, A., Svenningsson, B., Swietlicki, E., Tarozzi, L., Decesari, S., Facchini, M. C., Birmili, W., Sonntag, A., Wiedensohler, A., Boulon, J., Sellegri, K., Laj, P., Gysel, M., Bukowiecki, N., Weingartner, E., Wehrle, G., Laaksonen, A., Hamed, A., Joutsensaari, J., Petäjä, T., Kerminen, V.-M., and Kulmala, M.: EUCAARI ion spectrometer measurements at 12 European sites - analysis of new particle formation events, Atmos. Chem. Phys., 10, 7907-7927, doi:10.5194/acp-10-79072010, 2010.

Monson, R., Grote, R., Niinemets, U., and Schnitzler J. P.: Modeling the isoprene emission rate from leaves, New Phytol., 195, 541559, doi:10.1111/j.1469-8137.2012.04204.x, 2012.

Naik, V., Delire, C., and Wuebbles, D. J.: Sensitivity of global biogenic isoprenoid emissions to climate variability and atmospheric $\mathrm{CO}_{2}$, J. Geophys. Res., 109, D06301, doi:10.1029/2003JD004236, 2004.

Niinemets, $\ddot{U}$ and Reichstein, M.: Controls on the emission of plant volatiles through stomata: Differential sensitivity of emission rates to stomatal closure explained, J. Geophys. Res. 108, D74208, doi:10.1029/2002JD002620, 2003.

Niinemets, Ü., Monson, R. K., Arneth, A., Ciccioli, P., Kesselmeier, J., Kuhn, U., Noe, S. M., Peñuelas, J., and Staudt, M.: The leaflevel emission factor of volatile isoprenoids: caveats, model algorithms, response shapes and scaling, Biogeosciences, 7, 18091832, doi:10.5194/bg-7-1809-2010, 2010.

Oderbolz, D. C., Aksoyoglu, S., Keller, J., Barmpadimos, I., Steinbrecher, R., Skjøth, C. A., Plaß-Dülmer, C., and Prévôt, A. S. H.: A comprehensive emission inventory of biogenic volatile organic compounds in Europe: improved seasonality and landcover, Atmos. Chem. Phys., 13, 1689-1712, doi:10.5194/acp-131689-2013, 2013

Owen, S. M. and Penũelas, J.: Opportunistic emissions of volatile isoprenoids, Trends Plant Sci., 10, 420-426, 2005.

Pantin, F., Simonneau, T., Rolland, G., Dauzat, M., and Muller, B.: Control of Leaf Expansion: A Developmental Switch from Metabolics to Hydraulics, Plant Physiol., 156, 803-815, 2011.

Rautiainen, M., Heiskanen, J., and Korhonen, L.: Seasonal changes in canopy leaf are index and MODIS vegetation products for a boreal forest site in central Finland, Boreal Environ. Res., 17, 72-84, 2012

Rinne, J., Taipale, R., Markkanen, T., Ruuskanen, T. M., Hellén, H., Kajos, M. K., Vesala, T., and Kulmala, M.: Hydrocarbon fluxes above a Scots pine forest canopy: measurements and modeling, Atmos. Chem. Phys., 7, 3361-3372, doi:10.5194/acp-73361-2007, 2007

Rinne, J., Bäck, J., and Hakola, H.: Biogenic volatile organic compound emissions from the Eurasian taiga: current knowledge and future directions, Boreal Environ. Res., 14, 807-826, 2009.

Rohde, A. and Bhalerao, R. P.: Plant dormancy in the perennial context, Trends Plant Sci., 12, 217-223, 2007.

Schiestl-Aalto, P., Nikinmaa, E., and Mäkelä, A.: Duration of shoot elongation in Scots pine varies within crown and between years, Ann. Bot.-London, 112, 1181-1191, doi:10.1093/aob/mct180, 2013.

Seco R., Penuelas, J., and Filella, J.: Short-chain oxygenated VOCs: Emission and uptake by plants and atmospheric sources, sinks, and concentrations, Atmos. Environ., 41, 2477-2499, 2007.

Staudt, M., Bertin, N., Frenzel, B., and Seufert, G.: Seasonal variation in amount and composition of monoterpenes emitted by 
young Pinus pinea trees - implications for emission modeling, $\mathrm{J}$. Atmos. Chem., 35, 77-99, 2000.

Sutinen, S., Partanen, J., Viherä-Aarnio, A., and Häkkinen, R.: Anatomy and morphology in developing vegetative buds on detached Norway spruce branches in controlled conditions before bud burst, Tree Physiol., 29, 1457-1465, 2009.

Taipale, R., Ruuskanen, T. M., Rinne, J., Kajos, M. K., Hakola, H., Pohja, T., and Kulmala, M.: Technical Note: Quantitative long-term measurements of VOC concentrations by PTR-MS measurement, calibration, and volume mixing ratio calculation methods, Atmos. Chem. Phys., 8, 6681-6698, doi:10.5194/acp8-6681-2008, 2008.
Tarvainen, V., Hakola, H., Hellén, H., Bäck, J., Hari, P., and Kulmala, M.: Temperature and light dependence of the VOC emissions of Scots pine, Atmos. Chem. Phys., 5, 989-998, doi:10.5194/acp-5-989-2005, 2005.

Warneke, C., de Gouw, J. A., Kuster, W. C., Goldan, P. D., and Fall, R.: Validation of atmospheric VOC measurements by proton-transfer-reaction mass spectrometry using a gaschromatographic preseparation method, Environ. Sci. Technol., 37, 2494-2501, 2003.

Zeidler, J. and Lichtenthaler, H. K.: Biosynthesis of 2-methyl3-buten-2-ol emitted from needles of Pinus ponderosa via the non-mevalonate DOXP/MEP pathway of isoprenoid formation, Planta, 213, 323-326, 2001. 